
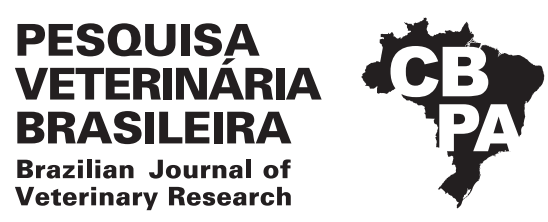

Pesq. Vet. Bras. 38(9):1761-1766, setembro 2018 DOI: $10.1590 / 1678-5150-P V B-5880$

Original Article

ISSN 0100-736X (Print)

ISSN 1678-5150 (Online)

\title{
Epidemiological and clinical-pathological aspects of fasciolosis in livers of cattle slaughtered in southern Brazil ${ }^{1}$
}

\author{
Lucas S. Quevedo ${ }^{2 *}$, Fábio R.P. Bruhn³ ${ }^{3}$ Jose L.R. Teixeira ${ }^{4}$, Taina S. Alberti², \\ Haide V. Scheid ${ }^{5}$, Margarida B. Raffi ${ }^{6}$, Eliza S.V. Sallis ${ }^{6}$ and Ana Lucia Schild ${ }^{7}$
}

\begin{abstract}
Quevedo L.S., Bruhn F.R.P., Teixeira J.L.R., Alberti T.S., Scheid H.V., Raffi M.B., Sallis E.S.V. \& Schild A.L. 2018. Epidemiological and clinical-pathological aspects of fasciolosis in livers of cattle slaughtered in southern Brazil. Pesquisa Veterinária Brasileira 38(9):17611766. Laboratório Regional de Diagnóstico, Faculdade de Veterinária, Universidade Federal de Pelotas, Campus Universitário, Pelotas, RS 96010-900, Brazil. E-mail: souzaquevedo@gmail.com

Infection by Fasciola hepatica is an important cause of economic loss in cattle raised in Brazil and others countries. In slaughterhouses, the losses are mainly associated with condemnation of livers; however, it is believed that these losses can extend to diminished carcass yield and productivity throughout the life of the animals. Three slaughterhouses with a daily routine of approximately 15-20 cattle slaughters were monitored from July 2016 to November 2017. After sample collection, weighing, and liver assessment, statistical studies were conducted to determine disease prevalence and measurement of economic losses caused by fasciolosis through condemnation of the organ of choice of the parasite. Of the 210 livers assessed, $79(37.6 \%)$ were condemned because of presence of $F$. hepatica, $87(41.4 \%)$ were considered appropriate for human consumption, and $44(20.9 \%)$ were considered inappropriate because of some other macroscopic lesions. The aim of this study was to estimate the prevalence of fasciolosis, correlate epidemiological and clinical-pathological aspects, and estimate the economic losses caused by the disease. It is estimated that the losses in southwestern Rio Grande do Sul state could reach $\mathrm{R} \$ 36,943,532.60(37.6 \% ; 95 \% \mathrm{CI}=30,753,525.80-43,526,55.65)$ or US $\$ 11,437,626.20$ (37.6\%; 95\% CI $=9,521,215.40-13,475,713.80)$ only because of condemnation of livers.
\end{abstract}

INDEX TERMS: Epidemiology, clinics, pathology, fasciolosis, liver, cattle, Fasciola hepatica, inspection, economic losses, post mortem examination, parasitoses.

RESUMO.- [Aspectos epidemiológicos e clínico-patológicos de fasciolose em fígados de bovinos abatidos no sul do Brasil.] A infecção por Fasciola hepatica é uma importante

\footnotetext{
${ }^{1}$ Received on March 26, 2018.

Accepted for publication on April 17, 2018.

${ }^{2}$ Resident in Animal Pathology, Faculdade de Veterinária (FV), Universidade Federal de Pelotas (UFPel), Campus Universitário, Pelotas, RS 96010-900, Brazil. *Corresponding author: souzaquevedo@gmail.com

${ }^{3}$ Departamento de Veterinária Preventiva, Faculdade de Veterinária (FV), Universidade Federal de Pelotas (UFPel), Campus Capão do Leão, Pelotas, RS 96010-900.

${ }^{4}$ Serviço de Inspeção Municipal de Pelotas, Av. Bento Gonçalves 4824, Pelotas, RS 96015-210, Brazil.

${ }^{5}$ Programa de Pós-Graduação em Veterinária, Faculdade de Veterinária (FV), Universidade Federal de Pelotas (UFPel), Campus Capão do Leão, Pelotas, RS 96010-900.

${ }^{6}$ Departamento de Patologia, Faculdade de Veterinária (FV), Universidade Federal de Pelotas (UFPel), Campus Capão do Leão, Pelotas, RS 96010-900.

${ }^{7}$ Laboratório Regional de Diagnóstico, Faculdade de Veterinária (FV), Universidade Federal de Pelotas (UFPel), Campus Universitário, Pelotas, RS 96010-900.
}

causa de prejuízos econômicos para o setor pecuário no Brasil e em outros países. Em frigoríficos, as perdas estão relacionadas principalmente a condenação dos fígados, porém acredita-se que esses prejuízos possam se estender a perdas no rendimento de carcaça e durante a vida produtiva do animal. Durante o período de julho de 2016 a novembro de 2017 foram realizados acompanhamentos periódicos mensais em três frigoríficos, os quais, possuem uma rotina diária de aproximadamente 15-20 abates. Após a coleta de dados, pesagem e avaliação dos fígados foram realizados estudos estatísticos para determinação da prevalência e mensuração dos prejuízos econômicos causados por fasciolose pela condenação do órgão de eleição do parasito. Dos 210 fígados avaliados, 79 $(37,6 \%)$ foram condenados devido a presença de F. hepatica, $87(41,4 \%)$ foram considerados próprios para consumo humano e $44(20,9 \%)$ impróprios por alguma outra alteração macroscópica. 0 objetivo deste estudo foi estimar a prevalência da fasciolose, e associar os aspectos epidemiológicos e clinico 
patológicos, além de estimar os prejuízos econômicos causados pela doença. Estima-se que as perdas na mesorregião Sudeste Rio-grandense possam chegar à $\mathrm{R} \$ 36.943 .532,60$ (37,6\%; IC. $95 \%=30.753 .525,80-43.526 .55,65)$ ou US $\$ 11.437 .626,20$ $(37,6 \%$; IC.95\% = 9.521.215,40-13.475.713,80) somente devido a condenação de fígados.

TERMOS DE INDEXAÇÃO: Epidemiologia, clinica, patologia, Fasciola hepatica, fígado, bovinos, inspeção, perdas econômicas, exame post mortem, parasitoses.

\section{INTRODUCTION}

Infection by Fasciola hepatica is an important cause of economic loss for the livestock sector in Brazil as well as in other countries such as Switzerland, Ethiopia, and Turkey (Knubben-Schweizer et al. 2010, Petros et al. 2013, Bennema et al. 2014, Chakiso et al. 2014, Bostanci \& Ŏguz 2017). In slaughterhouses, the losses are mainly associated with condemnation of livers; however, it is believed that these losses can extend to diminished carcass yield and productivity throughout the life of the animals (Andreani et al. 2017).

Disease occurrence is closely associated with times of heavy rainfall and wetlands because in these areas there is presence of aquatic planorbids, which are invertebrate hosts of the parasite (Tessele et al. 2013). Lymnaea columella and L. viatryx are the main species of invertebrate hosts found in Rio Grande do Sul state. They usually occur in low relief regions, as these areas enable accumulation of water and favor the development of metacercariae (infective form of Fasciola hepatica) (Müller 2007). However, in recent years, this parasite has been reported in the livers of animals from higher altitude regions of this state, such as the municipalities of Morro Redondo, 243 m a.s.l. (Siewert \& Silva 2012) and Canguçu, $466.57 \mathrm{~m}$ a.s.l. (Silva et al. 2012).

The fasciolosis trematode presents a heteroxenous life cycle with total duration of approximately four months, measures $2.5 \mathrm{~cm}$ in length and $1-1.5 \mathrm{~cm}$ in width, and can be easily observed macroscopically (Urquhart et al. 1996, Tessele et al. 2013). Mammals and birds that ingest water or vegetables containing metacercariae can become infected and develop the disease (Tessele et al. 2013). In the liver, immature forms cause injury because they migrate into the parenchyma, and adult forms are responsible for causing obstruction of the bile ducts (Fortes 2004).

Fasciolosis can present with acute, subacute or chronic form (Müller 2007). There may also be multiple 0.5-5 mm red areas distributed randomly in the hepatic parenchyma, irregular at cut, firm and edematous, and with hemorrhage in the bile ducts and fibrosis in the parenchyma (Adrien et al. 2013, Fiss et al. 2013). Animals may present with anemia, jaundice, distended gallbladder with thick edematous wall and multiple Fasciola hepatica specimens at different stages in its interior and spread in the hepatic parenchyma (Adrien et al. 2013). The acute form is responsible for the death of young sheep and cattle, and can cause developmental deficit and generate costs with treatments (Adrien et al. 2013, Fiss et al. 2013, Andreani et al. 2017).

In the chronic form of bovine fasciolosis, considered the most common, the main macroscopic changes observed are livers of pale color, with generally reduced left lobe size, thickening of the bile duct wall, and fibrosis (Tessele et al. 2013).
Calcification of these ducts and dilation of the gallbladder can also be observed; these lesions are characteristic in the bovine species (Paula et al. 2014). The chronic form of the parasite is of extreme importance in adult cattle, because it may interfere with productivity, weight gain, fertility, and amount and quality of milk (Gajewska et al. 2005, Petros et al. 2013, Andreani et al. 2017). In slaughterhouses, when inspection is properly performed, the ease of the macroscopic diagnosis guarantees reliability to rates of liver condemnation in slaughtered animals (Petros et al. 2013, Andreani et al. 2017).

This study aimed to determine the prevalence of fasciolosis responsible for liver condemnation in municipal inspection slaughterhouses in the southern region of Rio Grande do Sul state between 2016 and 2017, correlate the epidemiological and clinical-pathological aspects of fasciolosis, and estimate the economic loss caused by this disease in the region.

\section{MATERIALS AND METHODS}

Periodic monthly monitoring was conducted in three slaughterhouses from July 2016 to November 2017. All establishments were located in the southern region of Rio Grande do Sul state: one in the municipality of Arroio do Padre and two in the municipality of Pelotas. These slaughterhouses had a daily routine of approximately 15-20 cattle slaughters.

Diagnosis of fasciolosis was performed from macroscopic lesions during the slaughter of the animals. Veterinarians evaluated the livers in two stages along the E slaughter line: preparatory phase and examination of the organ. In the preparatory phase, the livers were removed from the carcasses, deposited on a table, washed with warm water $\left(38-40^{\circ} \mathrm{C}\right)$, and the regional lymph nodes were inspected. In the examination phase, the two faces of the organ were visually analyzed and then palpation, cross-section, and compression of the bile ducts were performed. The lymph nodes were longitudinally sectioned and the gallbladder was visually assessed, palpated and, when necessary, sectioned. If the liver presented any condition listed in the Regulation of Industrial and Sanitary Inspection of Animalorigin Products (RIISPOA), the organ was condemned in whole or partially (Brasil 2007). After macroscopic evaluation and weighing of the livers, samples were collected and fixed in $10 \%$ buffered formalin, embedded in paraffin, cut into 4-6 $\mu$ m sections, and stained with hematoxylin and eosin (HE) for subsequent microscopic assessment.

Descriptive statistical analysis of the data collected was performed, and prevalence of the disease was calculated throughout the study period. Sample size calculation was performed using epidemiological calculators - Epitools (Sergeant 2018), as described by Reiczigel et al. (2010). Prevalence was estimated using a 95\% confidence interval (CI. 95\%). During monitoring of the slaughter, the data from each batch were recorded, namely, sex, age, race, and municipality of origin, which were considered independent variables in the present study. The Pearson's chi-squared $\left(\chi^{2}\right)$ and Fisher's exact tests were applied to determine these variables in relation to disease occurrence considering a minimum chance of type I error of $5 \%(p<0.05)$.

Regarding analysis of economic loss due to fasciolosis, considering the satisfactory internal validity in relation to the prevalence verified in the present study, it was possible to estimate the losses by condemnation of livers infected with $F$. hepatica by simple calculation, assigning values of $\mathrm{R} \$ 8.90$ for each $\mathrm{kg}$ of liver; this value was obtained through a survey in the slaughterhouses of the municipalities. 


\section{RESULTS}

Of the 210 livers assessed, 79 (37.6\%; 95\% CI = 31.3-44.3) were condemned because of presence of Fasciola hepatica, 87 (41.4\%) were considered appropriate for human consumption, and $44(20.9 \%)$ were considered inappropriate because of other macroscopic lesions (hydatidosis, telangiectasia, hepatic abscess, cirrhosis, and steatosis).

The cattle were from ten municipalities of the southeast mesoregion of the state. Livers of animals parasitized by F. hepatica (Fig.1) were found in all of these municipalities. Of the total number of animals, 109 (51.9\%) were cows and 101 (48.1\%) were bulls; 177 (84.3\%) were from municipalities with wetlands and $33(15.7 \%)$ from municipalities with no wetlands, 99 (47.1\%) were beef cattle, 99 (47.1\%) were breeding cattle, and 12 (5.7\%) were dairy cattle.

Table 1 shows the results of the correlation of different factors with prevalence of $F$. hepatica. In these analyses, no significant differences were found with respect to age, sex, and utilization (dairy or beef cattle), as well as to origin: Bos taurus, Bos indicus, or B. taurus-B. indicus crossbreed.

Considering that each liver weighed $5.33 \mathrm{~kg}$ on average, and that a value of $R \$ 8.90$ was assigned per $\mathrm{kg}$, a loss due to fasciolosis of $\mathrm{R} \$ 3,747.52$ was estimated for the animals evaluated in the present study. Extrapolating these numbers to the total number of susceptible animals in the municipalities investigated, there was a loss of $R \$ 13,207,694.20(10,995,042.75$ to $15,561,707.85)$ or US\$ $4,089,069.40(3,404,038.00$ to $4,817,866,20$ ) (Table 2). Including only the mesoregion of the state (study area), which harbors 2,071,254 bovines (IBGE, 2016), more expressive values are reached: $\mathrm{R} \$ 36,943,532.60$ (37.6\%; $95 \% \mathrm{CI}=30,753,525.80$ to $43,526,55.65$ ) or US $\$ 11,437,626.20$ $(37,6 \% ; 95 \% \mathrm{CI}=9,521,215.40$ to $13,475,713.80)$.

All cattle infected with $F$. hepatica presented macroscopic lesions characterized by thickening of the biliary canaliculi with fibrosis, and some of them were obliterated due to the presence of multiple specimens of the parasite. At section, the ducts were calcified and presented sand-like appearance and/or dark brown and viscous exudate (bile, pus, epithelial lining cells, fragments and eggs of the parasite). The gallbladder was often enlarged. Some livers were pale, sometimes with atrophy of the left hepatic lobe (Fig.2).

Microscopic evaluation showed proliferation of fibrous connective tissue around the ducts and ductal hyperplasia (Fig.2). Inside the ducts, in addition to the adult parasite, there was also deposition of amorphous basophilic material (mineralization), inflammatory infiltrate of eosinophils, mononuclear cells and, in some cases, rare neutrophils. The macroscopic and histologic lesions observed in all cases were characteristic of chronic fasciolosis.

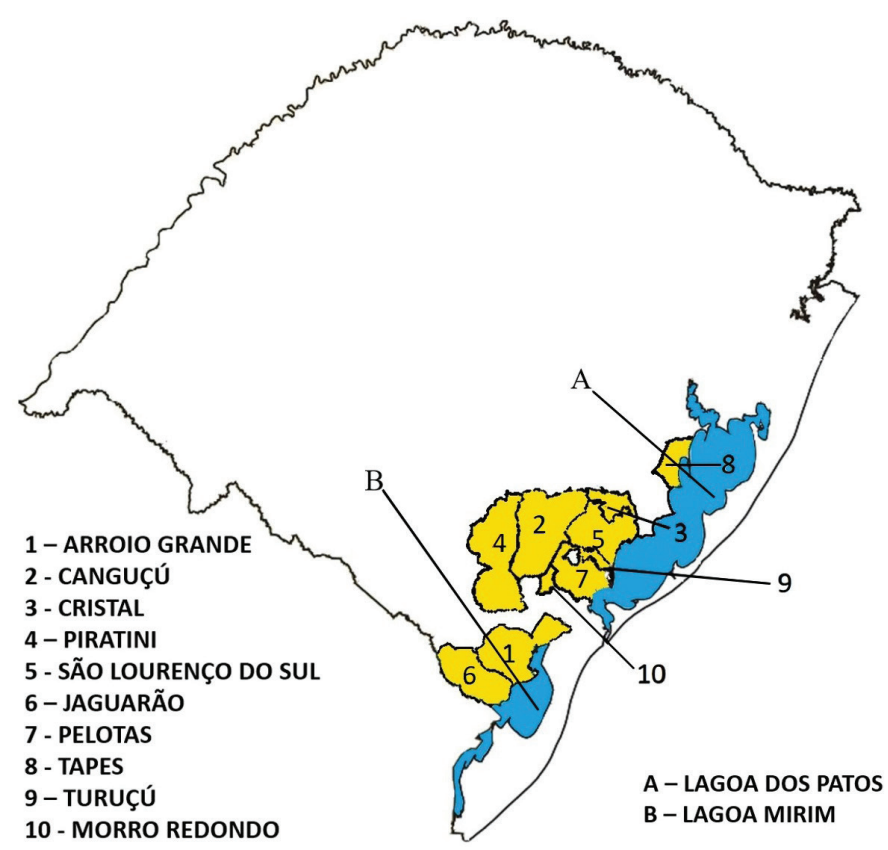

Fig.1. Municipalities of origin of the bovine herds investigated in the present study from 2016 to 2017 and the main wetlands that surround them.

Table 1. Factors associated with Fasciola hepatica infection of cattle regarding to age, sex, capability and subspecies in meat inspection in Pelotas, Rio Grande do Sul, 2016-2017

\begin{tabular}{|c|c|c|c|c|c|c|}
\hline \multirow{2}{*}{ Parameter } & \multirow{2}{*}{$\begin{array}{c}\text { Examined animals } \\
\mathrm{N} \\
\end{array}$} & \multicolumn{2}{|c|}{ Infected animals } & \multirow{2}{*}{$P$} & \multirow{2}{*}{ OR } & \multirow{2}{*}{ IC } \\
\hline & & $\mathrm{N}$ & Percentage & & & \\
\hline \multicolumn{7}{|l|}{ Age } \\
\hline $0-24$ months & 34 & 10 & $29.41 \%$ & 0.281 & 1.548 & $0.697-3.435$ \\
\hline$\geq 25$ months & 176 & 69 & $39.20 \%$ & & & \\
\hline \multicolumn{7}{|l|}{ Sex } \\
\hline Male & 101 & 32 & $31.68 \%$ & 0.087 & 1.635 & $0.929-2.876$ \\
\hline Female & 109 & 47 & $43.11 \%$ & & & \\
\hline \multicolumn{7}{|l|}{ Capability* } \\
\hline Cut & 99 & 42 & $42.42 \%$ & - & 1 & - \\
\hline $\mathrm{NDB}^{\mathrm{a}}$ & 99 & 31 & $31.31 \%$ & 0.105 & 0.619 & $0.346-1.108$ \\
\hline Milk & 12 & 6 & $50 \%$ & 0.617 & 1.357 & $0.409-4.505$ \\
\hline \multicolumn{7}{|l|}{ Origin } \\
\hline Bos taurus & 110 & 47 & $42.72 \%$ & 0.109 & 0.631 & $0.359-1.110$ \\
\hline Mixed breed & 100 & 32 & $32 \%$ & & & \\
\hline
\end{tabular}


Table 2. Economic losses caused by cattle liver condemnation due to Fasciola hepatica infection during meat inspection in Pelotas, Rio Grande do Sul, 2016-2017

\begin{tabular}{lrcccc}
\hline \multirow{2}{*}{ County } & Total of & Total cattle with 37.6\% & \multicolumn{2}{c}{ Estimated losses* } \\
\cline { 4 - 6 } & cattle $^{\mathrm{a}}$ & prevalence (IC=95\%, 31.3-44.3) & $\mathrm{R} \$$ & US\$ \\
\hline Arroio Grande & 108,465 & $40,783(33,949-48,050)$ & $1,934,623.10(1,610,438.70-2,279,347.85)$ & $598,954.50(498,587.80-705,680.45)$ \\
Canguçú & 135,164 & $50,822(42,306-59,878)$ & $2,410,843.20(2,006,869.70-2,840,432.70)$ & $746,391.00(621,321.90-879,390.90)$ \\
Cristal & 33,896 & $12,745(10,609-15,016)$ & $604,584.60(503,259.15-712,314.00)$ & $187,177.90(155,807.80-220,530.65)$ \\
Jaguarão & 99,051 & $37,243(31,003-43,879)$ & $1,766,696.10(1,470,689.30-2,081,488.10)$ & $546,965.75(455,321.75-644,423.55)$ \\
Morro Redondo & 15,031 & $5,642(4,705-6,659)$ & $268,113.90(223,191.10-315,883.00)$ & $83,007.40(69,099.40-97,796.60)$ \\
Pelotas & 50,433 & $18,963(15,785-22,342)$ & $899,547.80(748,793.05-1,059,837.45)$ & $278,497.80(231,824.50-328,123.05)$ \\
Piratini & 160,831 & $60,472(50,340-71,248)$ & $2,868,610.20(2,387,978.60-3,379,791.40)$ & $888,114.60(739,312.25-1,046,375.05)$ \\
São Lourenço & 96,098 & $36,133(30,079-42,571)$ & $1,714,041.10(1,426,857.50-2,019,440.50)$ & $530,662.90(441,751.55-625,213.80)$ \\
do Sul & & & & \\
Tapes & 24,941 & $9,378(7,806-11,049)$ & $444,864.20(370,293.20-524,131.40)$ & $137,728.85(114,641.90-162,269.80)$ \\
Turuçú & 16,609 & $6,245(5,199-7,358)$ & $296,244.00(246,625.00-349,041.45)$ & $91,716.40(76,354.50-108,062.40)$ \\
TOTAL & 740,519 & $278,426(231,782-328,050)$ & $13,207,694.20(10,995,042.75-15,561,707.85)$ & $4,089,069.40(3,404,038.00-4,817,866.20)$
\end{tabular}

* Losses through condemnation of cattle livers based on 37.6\% prevalence (IC=95\%, 31.3-44.3), considering medium weight of $5.33 \mathrm{~kg}$ for each liver (R\$ 8,90 per kg). a Source: IBGE 2015, ' Considering quotation of February 16, $2018=$ US\$1.00 $(\mathrm{R} \$ 3,23)$.
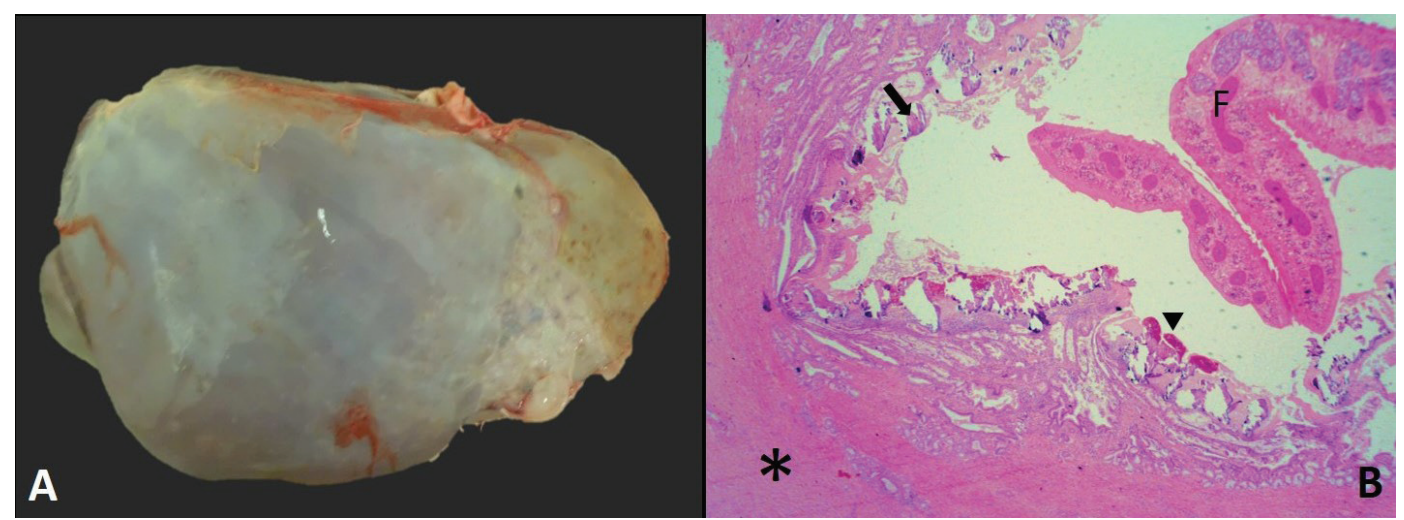

Fig.2. Liver of a female, raised for breeding, 7-years-old, $6150 \mathrm{~kg}$ bovine chronically parasitized by Fasciola hepatica. (A) Macroscopically, the organ is pale and with atrophy of the left lobe. (B) Microscopically, it is possible to observe an adult form of $F$. hepatica (F), thickening and proliferation of fibrous connective tissue (asterisks), mineralization (arrow), and pigment of F. hepatica (arrowhead). HE, obj.4x.

\section{DISCUSSION}

Prevalence of fasciolosisinthis study was $37.6 \%(95 \% \mathrm{CI}=31.3-44.3)$, slightly over two-fold the value observed by Bennema et al. (2014) in Rio Grande do Sul state, who reported prevalence of $14.39 \%$ in a sample of $8,427,727$ cattle between 2002 and 2011, and closer to the value found by Fruet et al. (2013), who described prevalence of $25.47 \%$ in the central region of the state with a sample of 9261 animals from 2010 to 2011. The high prevalence of fasciolosis compared with those of other causes of liver condemnation demonstrates the importance and economic impact that Fasciola hepatica can have on southern Rio Grande do Sul.

In the municipalities of origin of the cattle investigated in the present study, occurrence of this trematode is common because the environment in this region is favorable and both intermediate and definitive hosts are found (Mattos et al. 1997, Siewert \& Silva 2012, Adrien et al. 2013, Fiss et al. 2013). The environment in the south region of Rio Grande do Sul state is hot and humid, thus suitable for the development of the intermediate host (Lymnaea) (Tessele et al. 2013). Moreover, grazing of the ruminants (definitive hosts) in areas irrigated for rice cultivation favors the development of metacercariae, an infecting form of the parasite (Mattos et al. 1997).

According to Chakiso et al. (2014), fasciolosis occurs in upland regions with tropical and subtropical climate in Africa and Asia. These data corroborate the findings of this study, because the climate in the south of Brazil is subtropical and some animals came from high relief regions, such as the municipalities of Canguçu and Morro Redondo. Another determining factor for the occurrence of this disease is the presence of the infecting form of the parasite in times of heavy rainfall or during rice and soybean cultivation, when there is accumulation of water in marshy fields (Mattos et al. 1997).

In the present study, no significant difference was observed between male and female bovines with respect to development of fasciolosis. In Ethiopia (Chakiso et al. 2014) and Turkey (Bostanci \& Oğuz (2017), in studies conducted with samples of 384 and 140 livers, respectively, there was 
also no significant difference in disease occurrence between males and females.

Bostanci \& Oğuz (2017) assessed Brown Swiss, Simmental and crossbred bovines and observed that breed does not seem to have an impact on disease occurrence. In contrast, Chakiso et al. (2014) found statistically significant difference for Holstein cattle, which showed higher susceptibility than crossbred and Indian-origin animals respectively and, according to the authors, this can be explained by the high degree of immunity that cattle of Indian origin have acquired throughout their evolution - a result of the natural and repeated exposure of these bovines to the parasite, and this was not the case with animals of European origin (Bos taurus). In the present study, it was not possible to make this comparison, because animals of Indian origin are not raised in large numbers in the study region due to their genotypic characteristics. However, no statistical difference was observed regarding disease prevalence for Bos taurus and Bos taurus-Bos indicus crossbred animals. In the state of Rio Grande do Sul, the climatic conditions favor raising of European-origin cattle, and B. indicus-purebred animals are rarely found in the region, as well as in the slaughterhouses of the municipalities investigated.

It has been reported that cattle aged 1-2 years are more susceptible to fasciolosis (Petros et al. 2013, Chakiso et al. 2014, Bostanci \& Oğuz 2017). Enzyme-linked Immunosorbent Assays (ELISA) showed prevalence of $41.9 \%$ and $31.2 \%$ in cattle aged 1-2 and 3-5 years, respectively, with statistically significant difference between the two groups $(p<0.05)$ (Bostanci \& Oğuz 2017). In the present survey, bovines aged $>2$ years presented higher prevalence of hepatic lesions compared with that of cattle aged 1-2 years, but without statistically significant difference between groups. It has been suggested that cattle acquire immunity over the years, as they are exposed to the parasite agent and, as a consequence, they present greater resistance over time (Acosta 1994). In contrast, it should be considered that, in the study region, cattle aged 1-2 years are slaughtered in lesser proportion than those aged $>2$ years, and this may have influenced the higher disease prevalence of the latter.

Overall, adult cattle do not develop apparent clinical signs after mild infections, but some studies have reported that infected animals may present diminished carcass yield and decreased reproduction and milk production indexes, causing economic losses throughout their lives (Gajewska et al. 2005, Petros et al. 2013, Andreani et al. 2017). The acute form of the disease is seldom reported in adult cattle; however, in an area considered endemic in Rio Grande do Sul state, of a batch of 70 cows aged approximately 3 years, 10 animals aborted and five died with clinical signs and lesions characteristic of acute fasciolosis (Adrien et al. 2013).

In this study, no losses in carcass yield were observed by means of subjective evaluation, that is, animals with marked hepatic lesions presented satisfactory body condition and animals with medium-to-low body condition occasionally presented livers appropriate for human consumption. For this reason, most rural producers and veterinaries do not prioritize the techniques of control and prophylaxis of bovine fasciolosis. The most significant losses observed in this study were due to condemnation of livers infected with $F$. hepatica. In contrast, other studies have demonstrated diminished carcass yield in affected animals, with the highest prevalence of fasciolosis (37.11\%) observed in animals with poor body condition and lowest prevalence $(11.11 \%)$ found in cattle with satisfactory body condition (Petros et al. 2013).

\section{CONCLUSIONS}

This study conducted in the southern region of Rio Grande do Sul state demonstrated that fasciolosis is an important parasitic disease of cattle that, although it does not cause losses by death, can lead to expressive indexes of condemnation of livers in this animal species.

No significant differences were observed regarding the occurrence of hepatic lesions caused by fasciolosis between the different cattle breeds present in the region, beef and dairy cattle, or male and female bovines.

Acknowledgements.- The authors are grateful to the Municipal Inspection Service of Pelotas.

\section{REFERENCES}

Acosta D. 1994. Epidemiologia y control de Fasciola hepatica en el Uruguay, p.233-256. In: Nari A. \& Fiel C. (Eds), Enfermidades Parasitárias de Importancia Economica en Bovinos. Editorial Hemisferio Sur, Montevideo.

Adrien M.L., Schild A.L., Marcolongo-Pereira C., Fiss L., Ruas J.L., Grecco F.B. \& Raffi M.B. 2013. Acute fasciolosis in cattle in southern Brazil. Pesq. Vet. Bras. 3(6):705-709. <http://dx.doi.org/10.1590/S0100-736X2013000600003>

Andreani L.H., Lemfers T.R., Faustino F.P., Nogueira C.E. \& Luz T.V.B. 2017. Descarte de fígados bovinos por fasciolíase hepática em Santa Catarina, Brasil. Revta CFMV 13(73):66-71.

Bennema S.C., Scholte R.G.C., Molento M.B., Medeiros C. \& Carvalho O.S. 2014. Fasciola hepatica in bovines in Brazil: data availability and spatial distribution. Revta Inst. Med. Trop. São Paulo 56(1):35-41.

Bostanci A. \& Oğuz B. 2017. Copro-ELISA prevalence of Fasciola hepatica in cattle in Van, Turkey. Acta Scient. Vet. 45(1465):1-7.

Brasil. Ministério da Agricultura, Pecuária e Abastecimento 2007. Inspeção de Carnes Bovina: padronização de técnicas instalações e equipamentos. MAPA/DIPOA, Brasília. 168p.

Chakiso B., Menkir S. \& Desta M. 2014. On farm study of bovine Fasciolosis in Lemo district and its economic loss due to liver condemnation at Hossana Municipal abattoir, southern Ethiopia. Int. J. Curr. Microbiol. Appl. Sci. 3(4):1122-1132.

Fiss L., Lourdes Adrien M., Marcolongo-Pereira C., Assis-Brasil N.D., Sallis E.S., Riet-Correa F., Ruas J.L. \& Schild A.L. 2013. Subacute and acute fasciolosis in sheep in southern Brazil. Parasitol. Res. 112(2):883-887.<http://dx.doi. org/10.1007/s00436-012-3096-2><PMid:22941529>

Fortes E. 2004. Parasitologia Veterinária. 4ª ed. Editora Ícone Ltda, Rio de Janeiro. 607p.

Fruet A.P.B., Fabrício E.A., Kirinus J.K., Scortegagna A., Dörr A.C. \& Nörnberg J.L. 2013. Perdas econômicas oriundas das condenações de vísceras bovinas em matadouros de Santa Maria, Rio Grande do Sul. Revta Bras. Ciênc. Vet. 20(2):99-103. <http://dx.doi.org/10.4322/rbcv.2014.053>

Gajewska A., Smaga-Kozłowska K. \& Wiśniewski M. 2005. Pathological changes of liver in infection of Fasciola hepatica. Wiad. Parazitol. 51(2):115-123. $<$ PMid:16838620>

IBGE 2016. Efetivo dos rebanhos, por tipo de rebanho. Brasília. Available at <https://sidra.ibge.gov.br/tabela/3939\#resultado> Access on Feb. 5, 2018.

Knubben-Schweizer G., Rüegg S., Torgerson P.R., Rapsch C., Grimm F., Hässig M., Deplazes P. \& Braun U. 2010. Control of bovine fasciolosis in dairy cattle 
in Switzerland with emphasis on pasture management. Vet. J. 186(2):188191. <http://dx.doi.org/10.1016/j.tvjl.2009.08.003><PMid:19758828>

Mattos M.J.T., Ueno H., Gonçalves P.C. \& Almeida J.E.M. 1997. Ocorrência estacional e bioecologia de Lymnaea columella Say, 1817 em habitat natural no Rio Grande do Sul. Revta Bras. Med. Vet. 19:248-252.

Müller G. 2007. Doenças parasitárias: fasciolose, p.639-650. In: Riet-Correa F., Schild A.L., Lemos R.A.A. \& Borges J.R.J. (Eds), Doenças de Ruminantes e Equinos. Vol.1. $3^{\mathrm{a}}$ ed. Pallotti, Santa Maria.

Paula F.M.A.B., Sousa D.R., Archanjo A.B., Carvalho J.R. \& Nunes L.C. 2014. Caracterização histológica de fígados bovinos com fasciolose crônica. Archs Vet. Sci. 19(4):57-64. <http://dx.doi.org/10.5380/avs.v19i4.35785>

Petros A., Kebede A. \& Wolde A. 2013. Prevalence and economic significance of bovine fasciolosis in Nekemte Municipal abattoir. J. Vet. Med. Anim. Health 5(8):202-205.

Reiczigel J., Földi J. \& Ozsvári L. 2010. Exact confidence limits for prevalence of a disease with an imperfect diagnostic test. Epidemiol. Infect. 138(11):16741678. <http://dx.doi.org/10.1017/S0950268810000385><PMid:20196903>
Sergeant E.S.G. 2018. Epidemiological calculators. Ausyet Pty Ltd. Available at <http://epitools.ausvet.com.au> Access on Feb. 21, 2018.

Siewert R.R. \& Silva E.J.E. 2012. Ocorrência de lepidópteros de importância médica (Lepidoptera: Aididae, Lasiocampidae, Limacodidae e Megalopygidae) no Cerro da Buena, município de Morro Redondo, Rio Grande do Sul, Brasil. Biotemas 25(4):279-283. <http://dx.doi.org/10.5007/21757925.2012v25n4p279>

Silva G.L., Silva A.S. \& Yamasaki Y. 2012. Validação da assimilação de dados na inferência da refletividade de um radar com o sistema mm5. Revta Bras. Meteorol. 27(1):75-84. <http://dx.doi.org/10.1590/S010277862012000100008>

Tessele B., Brum J.S. \& Barros C.S.L. 2013. Lesões parasitárias encontradas em bovinos abatidos para consumo humano. Pesq. Vet. Bras. 33(7):873-889. <http://dx.doi.org/10.1590/S0100-736X2013000700008>

Urquhart G.M., Armour J., Duncan J.L., Dunn A.M. \& Jennings F.W. 1996. Veterinary Parasitology. 2nd ed. Blackwell, Oxford. 307p. 